\title{
EVALUATION OF THE EFFECT OF ELASTIC BANDAGE ON THE ANKLE BASKETBALL PLAYERS WITH AND WITHOUT CHRONIC INSTABILITY
}

\author{
AVALIAÇÃO DO EFEITO DA BANDAGEM ELÁSTICA NO TORNOZELO DE JOGADORES DE BASQUETE \\ COMESEM INSTABILIDADE CRÔNICA
}

EVALUACIÓN DEL EFECTO DE L VENDAJE ELÁSTICA EN EL TOBILLO DEATLETAS DEBALONCESTO CON
YSIN INESTABILIDAD CRÓNICA

Henrique Hahn Souza

(Physiotherapist)

Ivan Pacheco 2,3

(Physician)

Luiza Cammerer Gehrke'

(Physiotherapist)

Gabriel Pizetta de Freitas ${ }^{1}$

(Physiotherapist)

Renata Fanfa Loureiro-Chaves'

(Physiotherapist)

Adriana Moré Pacheco ${ }^{1}$

(Physiotherapist)

\section{Universidade Federal do Rio Grande do Sul, Porto Alegre, RS, Brazil. 2. Grêmio Náutico União, Porto \\ Alegre, RS, Brazil. \\ 3. Federação Gaúcha de Futebol, \\ Porto Alegre, RS, Brazil}

\section{Correspondence:}

Adriana Moré Pacheco.

Escola de Educação Física,

Fisioterapia e Dança. Universidade

Federal do Rio Grande do Sul.

Felizardo, 750, Porto Alegre,

RS, Brazil. 90690-200.

adrimpacheco@ufrgs.br

\begin{abstract}
Introduction: Basketball is a sport that requires good motor coordination as well as intense and multidirectional movements. Chronic ankle instability affects about $40 \%$ of patients who have sustained a sprain injury. In order to minimize the effects of this dysfunction, functional elastic tape has been widely used due to its mechanical properties, having some positive effects on athletes' functional performance. Objective: To evaluate the effect of elastic tapes on the ankles of basketball players with and without chronic instability. Method: Thirteen athletes from a varsity basketball team of both sexes, aged between 18 and 30 years ( $23.2 \pm 3.2$ years), who had been playing the sport for at least one year and trained at least twice a week. The subjects were assessed using the anterior drawer test for the presence or absence of chronic ankle instability and in three different situations: placebo, elastic tape and control, and the order of use of the implements was randomly determined, using the Star Excursion Balance Test (SEBT) to assess the ankle stability of these athletes. Results: Among the eight directions proposed in the SEBT, there was statistical significance in the difference in three directions for the placebo method in comparison to elastic taping and control. There was no statistical significance in the difference in four directions between the assessments, and there was no statistical significance in the difference in all directions between the control and elastic tapes. Conclusion: It can be inferred from the study that elastic taping does not have positive effects on joint stability in athletes with and without chronic instability, taking into account their functionality. Levef of Evidence l; High quality randomized trial with statistically significant difference or no statistically significant difference but narrow confidence intervals.
\end{abstract}

Keywords: Athletic tape; Ankle; Athletes.

\section{RESUMO}

Introdução: O basquete é um esporte que requer boa coordenação motora e movimentos intensos e multidirecionais. A instabilidade crônica de tornozelo acomete cerca de $40 \%$ dos pacientes que sofreram lesão por entorse. Visando minimizar os efeitos dessa disfunção, a fita atlética elástica vem sendo bastante usada por suas propriedades mecânicas, apresentando alguns efeitos positivos sobre o desempenho funcional dos atletas. Objetivo: Avaliar o efeito da fita atlética elástica no tornozelo de jogadores de basquete com e sem instabilidade crônica. Método: Foram avaliados 13 atletas de times de basquete universitário, de ambos os sexos, com idade entre 18 e 30 anos (23,2 23,2 anos), que praticavam a modalidade há pelo menos um ano, com frequência de treino de, no mínimo, duas vezes por semana. Os sujeitos foram avaliados pelo teste de gaveta anterior quanto à presença ou não de instabilidade crônica de tornozelo em três situações distintas: com placebo, com fita atlética elástica e controle, e a ordem de uso dos implementos foi randomicamente determinada, sendo aplicado o Star Excursion Balance Test (SEBT) para avaliar a estabilidade do tornozelo desses atletas. Resultados: Entre as oito direções propostas no SEBT, houve significância estatística na diferença em três direções para o placebo, com relação à fita atlética elástica e o controle. Não houve significância estatística na diferença em quatro direções entre as avaliações e não houve significância estatística na diferença em todas as direções entre as avaliações controle efita atlética elástica. Conclusão: A partir deste estudo, foi possível observar que a fita atlética elástica não tem efeitos positivos sobre a estabilização articular em atletas com e sem instabilidade crônica em termos da avaliação da funcionalidade. Nível de Evidência l; Estudo clínico randomizado de alta qualidade com ou sem diferença estatisticamente significante, mas com intervalos de confiança estreitos.

Descritores: Fita atlética; Tornozelo; Atletas.

\section{RESUMEN}

Introducción: El baloncesto es un deporte que requiere una buena coordinación motora y movimientos intensos y multidireccionales. La inestabilidad crónica del tobillo afecta a aproximadamente el $40 \%$ de los pacientes que han sufrido una lesión de esguince. Con el fin de minimizar los efectos de este trastorno, la cinta atlética elástica viene siendo bastante usada por sus propiedades mecánicas, presentando algunos efectos positivos en el rendimiento funcional de los atletas. Objetivo: Evaluar el efecto de la cinta atlética elástica en el tobillo de jugadores de baloncesto con y sin inestabilidad crónica. Método: Fueron evaluados 13 atletas del equipo de baloncesto universitario, de ambos sexos, con edad entre 18 y 30 años 
(23,2 \pm 3,2 años), que practicaban la modalidad desde hace por lo menos un año, con frecuencia de entrenamiento de, como mínimo, dos veces por semana. Los sujetos fueron evaluados por el test de cajón anterior cuanto a la presencia o no de inestabilidad crónica del tobillo en tres situaciones diferentes: con placebo, con cinta atlética elástica y control, y el orden de uso de los implementos aleatoriamente determinado, siendo aplicado el Star Excursion Balance Test (SEBT) para evaluar la estabilidad del tobillo de estos atletas. Resultados: Entre las ocho direcciones propuestas en el SEBT, hubo significancia estadística en tres direcciones para el placebo, con relación a la cinta atlética elástica y el control. No hubo significancia estadística en la diferencia en cuatro direcciones entre las evaluaciones y no hubo significancia estadística en la diferencia en todas las direcciones entre las evaluaciones control y cinta atlética elástica. Conclusión: A partir de este estudio, fue posible observar que la cinta atlética elástica no tiene efectos positivos sobre la estabilización articular en atletas con y sin inestabilidad crónica, en términos de evaluación de la funcionalidad. Nivel de Evidencia l; Estudio clínico aleatorio de alta calidad, con o sin diferencia estadísticamente significativa, pero con estrechos intervalos de confianza.

Descriptores: Cinta atlética; Tobillo; Atletas.

\section{INTRODUCTION}

The area of sports rehabilitation constantly presents new techniques of therapeutic procedures for both prophylaxis and treatment of injuries, among them elastic tape, also known as Kinesiotaping ${ }^{\circledast}(K T)^{1}$. Released in the early 1980's by the Japanese Kenso Kase, the primary objectives of KTs are to improve blood circulation, reduce oedema, facilitate muscle activity as well as inhibit it, and improve joint function by improving sensory mechanisms ${ }^{2}$. KT, unlike other tapes, does not limit range of motion and function, and it is called elastic functional tape. The tape can be applied with different degrees of tension due to its elastic property, which allows an extension of $40 \%$ to $60 \%$ from its original length ${ }^{3}$.

The functional elastic tape has demonstrated some positive effects on performance through its mechanical properties, serving as support for muscles and fascia, and improving joint misalignment ${ }^{4}$. Considering the elastic component, KT has a stabilizing action through its effects on proprioception and muscle activation rather than serving as a mechanical support, increasing the functional stability of the ankle?

The ankle is the most affected joint in sports such as soccer, volleyball, handball and basketball ${ }^{5,6,7}$ and inversion sprains are the most frequent injuries in athletes of such sports ${ }^{5,6,8}$. According to Bicci et al $^{7}$, around $40 \%$ of patients who suffered a sprain injury develop a chronic ankle instability (ICS) as a result and present deficits in functional performances. Proprioception is clearly impaired after an ankle sprain, damaging the transmission of peripheral information of joint stability and postural contro $^{5,8}$. KT exerts stimulation in the extrinsic mechanoreceptors, so it is believed to improve the transmission of the previously mentioned peripheral information, playing a fundamental role in the prevention?

Due to the lack of consensus in the literature on the subject, it is of utmost importance that more studies verify whether this implement has positive effects on the stabilization of the joint also taking into account the functionality of the athletes. Thus, the present study aimed to evaluate the effect of elastic tape on the ankle of basketball athletes with and without chronic instability.

\section{METHODOLOGY}

The sample size was calculated from the study by Bicci et al ${ }^{7}$ with a significance level of 5\%, a standard deviation of 8.82 and a mean of 85.05 $\mathrm{cm}$ in SEBT. The optimal sample size was considered to be a minimum of 12 athletes; however, considering a possible sample loss of 10\%, a size of 13 athletes is suggested.

The research was carried out in a quantitative character with a cross-sectional randomized clinical trial ${ }^{10}$ composed of basketball athletes, from the Federal University of Rio Grande do Sul, with ages ranging from 18 to 30 years ( $23.2 \pm 3.2$ years), and a training frequency of at least twice a week. The exclusion criteria were having local allergy to the material of the tapes; interrupting the test; having history of lower limb surgery and having had any lower limb injury in the last three months.

As soon as they agreed to participate in the research, the athletes signed the free and informed consent form approved by the Research Ethics Committee of the university, on May $5^{\text {th }}$ of 2016 , under the number CAAE 54408916.1.0000.5347 and opinion 675.860, in accordance with Resolution 466/2012 of the National Health Council.

The data collection took place in the Physical Therapy Clinic on the university. At such day, all athletes answered a questionnaire with questions regarding private identification, sports practice and history of lower limb injuries. In addition, the anterior drawer test to assess the presence or absence of functional ankle joint instability (Figure 1 and Figure 2) was performed by an experienced medical doctor who did not know the athletes.

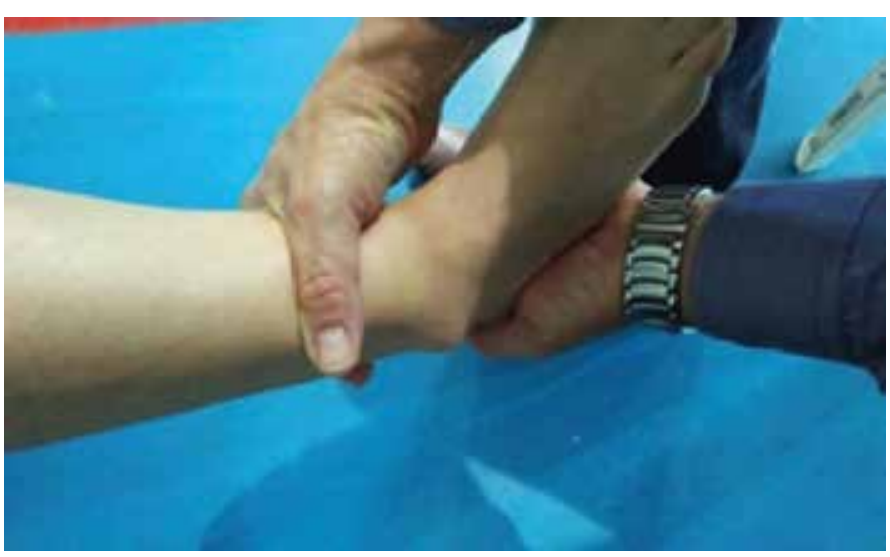

Figure 1. Negative anterior drawer test.

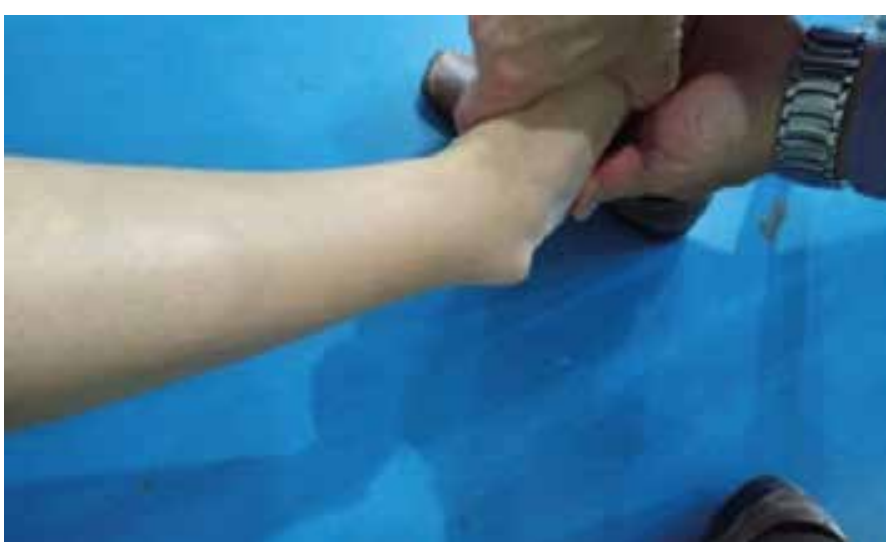

Figure 2. Positive anterior drawer test. 
At first, each of the subjects performed a warm-up (running for 5 minutes on a treadmill at a speed defined by the athlete), and then went through tape application (KT), depending on the study situation defined through a simple draw between three situations of the study: placebo, elastic tape and control. The situations are the following: 1) placebo method followed by the study by Bicci et al. ${ }^{7}$, with the KT arranged in two vertical strips passing through the lateral and medial malleolus and two strips arranged in " $x$ " from the upper end of one strip to the lower end of the other strip without tension (Figure 3); 2) method with elastic tape followed the study by Kuni et al. ${ }^{11}$ which consisted of the application on the plantar region of the hind foot to leave two halves, one medial and one lateral to the ankle. The medial half was applied with $100 \%$ tension towards the distal part of the medial gastrocnemius, passing through the internal malleolus and ending just above it. The lateral half was applied on the same way, however, towards the lateral region of the leg, terminating at the same height of the medial part of the tape (Figure 4 and 3) the control method with no tape placement and no other implement. Finally, after each situation on different days, the athletes were assessed for ankle instability through the Star Excursion Balance Test (SEBT) (Figure 5).

Both applications of tapes were preceded by shaving and hygienization of the skin with ethyl alcohol 70\% hydrated. The elastic tape had its ends rounded before application. The study collection stages were performed by two different evaluators: one trained for the placement of the tapes and the other a blind evaluator.

The SEBT consisted of a series of one-sided mini-squats held in the centre of a wind rose while attempting to reach as far as possible in each of the eight directions with the opposite leg. It is considered that the greater the distance reached in the test, the better the functional performance

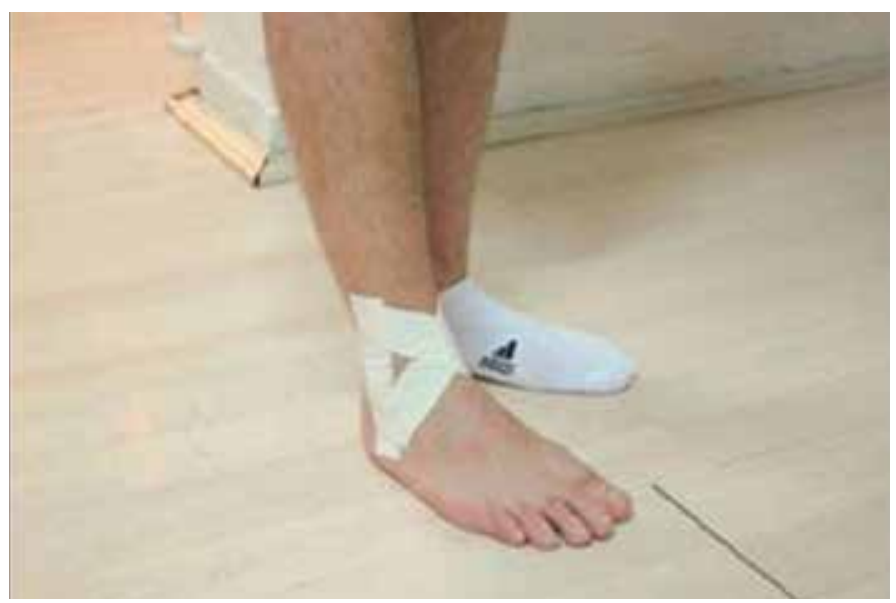

Figure 3. Placebo tape application. of the subject and the greater the stability of the ankle. There is a relation between the distance and demand regarding neuromuscular balance and control systems ${ }^{6}$. For the SEBT, the panel from the study by Peres et al. ${ }^{6}$ was positioned on the floor. On each day of collection, the test was preceded by a familiarization and then it was performed three times, with an average of centimetres recorded for each of the eight directions. The athletes performed the test with their hands at the waist, kept the support foot flat on the floor using sneakers. Between each of the three situations, they had a rest time of approximately one and a half minutes.

\section{Statistical analysis}

quantitative variables were described by mean and standard deviation or interquartile range and median. Qualitative variables were described by absolute and relative frequencies. To compare the SEBT results between the three groups (placebo, elastic tape and control), Analysis of Variance (ANOVA) for repeated measures complemented by the Bonferroni test was applied. The significance level adopted was $5 \%(p<0.05)$ and the analyses were performed in the SPSS program version 21.0 (University of Chicago, United States).

\section{RESULTS}

Thirteen university basketball athletes met the study inclusion criteria, four female athletes and nine male athletes with a mean age of 23.2 \pm 3.2. Sample characterization data are presented in Table 1. Of these, nine were evaluated as having stable ankles and four with functional instability from the results obtained by the drawer test. No athlete was sensitive to the tape material, nor interrupted the SEBT test.

After the evaluation for the presence or absence of functional instability, the performance of the athletes was compared regarding the SEBT test. The results showed, among the eight directions proposed in the SEBT, statistical significance in four directions (posterior lateral, posterior medial, posterior and lateral) for the placebo method in relation to the elastic tape and control. There was no statistically significant difference in four directions (anterior, anterior medial, anterior lateral and medial) between the evaluations and there was no statistical significance in all directions between the control and elastic tape situations (Table 2).

\section{DISCUSSION}

This study sought to verify the effect of elastic tape on ankle stability and instability of basketball athletes and whether this effect is similar when the situation involves a placebo application.

Elastic tape is one of the most common therapeutic resources in sports therapy and it can be used for prevention, rehabilitation of injuries and improvement of performance. One of the hypotheses of its effects is the interaction between the afferent cutaneous stimulation and the motor unit, involving the central and peripheral nervous system ${ }^{12}$. In addition, it

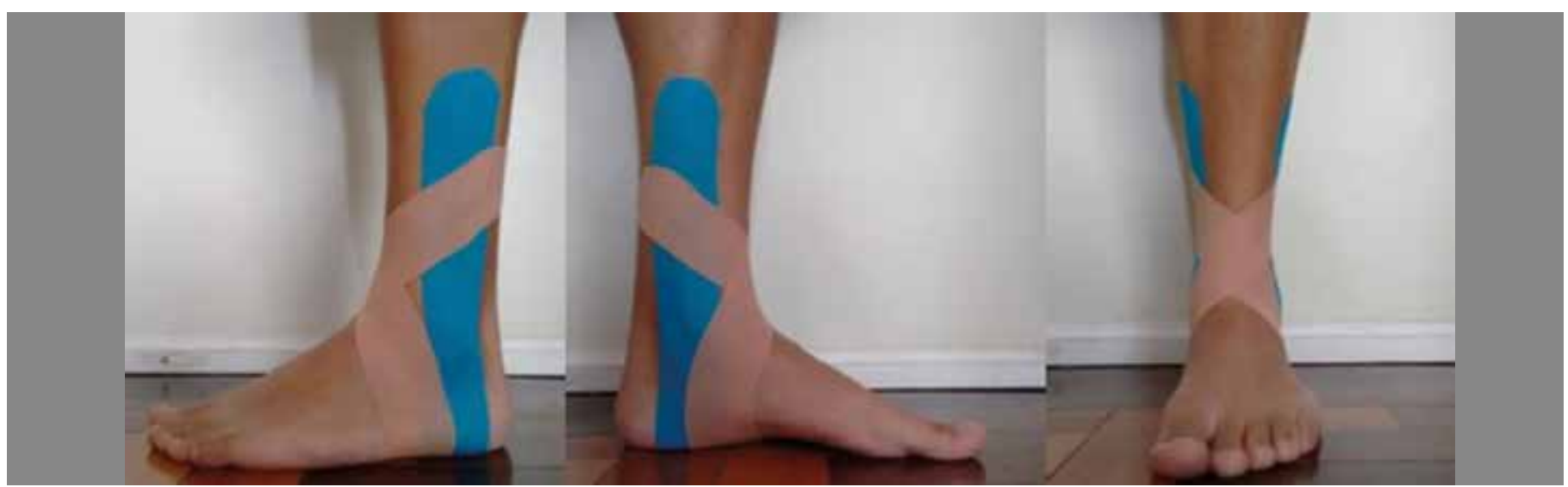

Figure 4. Kinesiotaping ${ }^{\circledR}$ application method. 
With the left lower limb

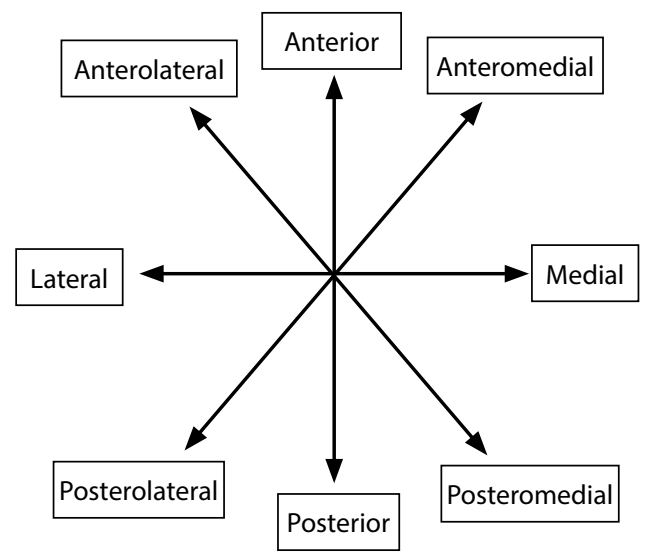

With the right lower limb

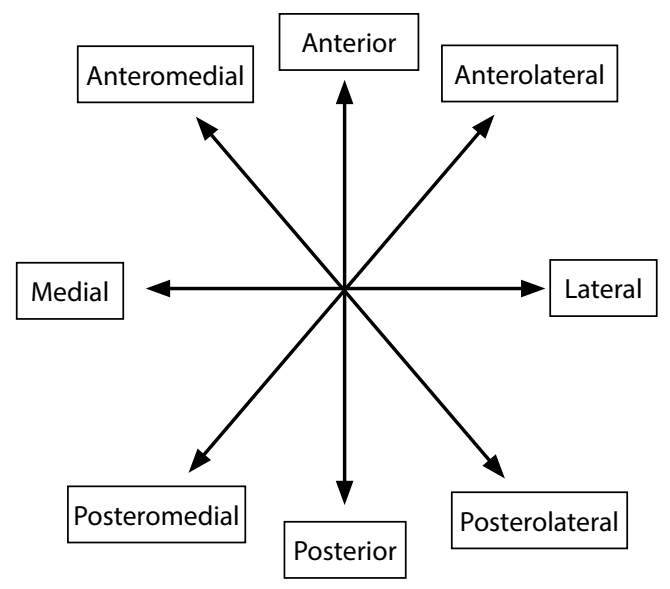

Figure 5. Star Excursion Balance Test (SEBT).

Table 1. Sample Characterization.

\begin{tabular}{c|c}
\hline Variables & $\mathbf{n}=\mathbf{1 3}$ \\
\hline Age (years) - mean \pm SD & $23,2 \pm 3,2$ \\
\hline Sex $-\mathrm{n}(\%)$ & \\
\hline Male & $9(69,2)$ \\
\hline Female & $4(30,8)$ \\
\hline Training Frequency $-\mathrm{n}(\%)$ & $8(61,6)$ \\
\hline $2 \mathrm{x}$ & $5(38,5)$ \\
\hline $3 \mathrm{x}$ & $3(1-5)$ \\
\hline Number of sprains & $6(4-13)$ \\
\hline Time since last sprain (months) & $4(30,8)$ \\
\hline Drawer Test $-\mathrm{n}(\%)$ & $9(69,2)$ \\
\hline With Instability &
\end{tabular}

Table 2. Comparison between Evaluations.

\begin{tabular}{c|c|c|c|c}
\hline Directions & Control & Placebo & Tape & P \\
\hline & Mean \pm SD & Mean \pm SD & Mean \pm SD & \\
\hline Anterior & $71,2 \pm 6,2$ & $73,1 \pm 5,5$ & $71,4 \pm 6,0$ & 0,692 \\
\hline Anterior Medial & $75,5 \pm 5,9$ & $78,2 \pm 5,0$ & $77,1 \pm 5,7$ & 0,103 \\
\hline Medial & $78,1 \pm 10,3^{\mathrm{a}}$ & $83,6 \pm 7,0^{\mathrm{b}}$ & $79,8 \pm 6,9^{\mathrm{ab}}$ & 0,002 \\
\hline Posterior Medial & $82,7 \pm 12,3^{\mathrm{a}}$ & $90,9 \pm 7,5^{\mathrm{b}}$ & $84,8 \pm 7,8^{\mathrm{a}}$ & 0,005 \\
\hline Posterior & $83,8 \pm 15,3^{\mathrm{a}}$ & $94,5 \pm 8,6^{\mathrm{b}}$ & $86,0 \pm 9,5^{\mathrm{a}}$ & 0,001 \\
\hline Posterior Lateral & $75,0 \pm 15,0^{\mathrm{a}}$ & $84,5 \pm 9,0^{\mathrm{b}}$ & $78,1 \pm 9,8^{\mathrm{a}}$ & 0,004 \\
\hline Lateral & $63,5 \pm 11,5^{\mathrm{a}}$ & $72,8 \pm 8,1^{\mathrm{b}}$ & $67,4 \pm 7,7^{\mathrm{a}}$ & 0,003 \\
\hline Anterior Lateral & $61,0 \pm 5,4$ & $62,4 \pm 4,2$ & $61,5 \pm 5,8$ & 0,680 \\
\hline
\end{tabular}

$\mathrm{a}, \mathrm{b}$ Equal letters present no different in Bonferroni Test with $5 \%$ of significance.

is believed that elastic tape stimulates the recruitment of motor neuron, leading to an increase in muscle tone and improving joint stabilization as a consequence ${ }^{3}$. Considering the athletic gestures such as jumping, lateral displacement and running, the use of tape is indicated as a prophylactic measure for basketball athletes, due to its proprioceptive and mechanical benefits suitable for increasing joint stability ${ }^{14}$.

The study by Sawkins and Refshauge ${ }^{12}$ compared the use of elastic tape, control and placebo situations in three positions of the SEBT, and found no significant difference between these conditions, showing that tape did not improve functional performance, being contrary to this study in the comparison between elastic tape and control.

Another investigation compared the use of elastic tape with a placebo method on balance through SEBT, and showed that Kinesiotaping ${ }^{\circledR}$ did not show differences in performance, leading the authors to conclude that KT was not able to improve motor control of athletes ${ }^{15}$.
Also, Halseth et al. ${ }^{16}$ investigated the effect of KT on proprioception in subjects without previous severe ankle injury and concluded that when applied to the lower leg and ankle the implement did not provide an increase in proprioceptive response.

Many studies have attempted to present evidence of the use of elastic tape as a preventive measure in chronic ankle instability, but Briem et al. ${ }^{2}$ point out that its effect is contradictory due to the fact that sometimes the tape does not act on fibular muscles, that are important stabilizers of this joint. According to the study by Hettle et al. ${ }^{17}$, the use of KT did not demonstrate significant effects on the (SEBT), showing that KT seems to be irrelevant to improve functional performance of chronically unstable ankles.

In contrast, Kwiatkowska et al. ${ }^{18}$ found significant results regarding functional capacity of patients with acute ankle sprain. In a recent systematic review ${ }^{13}$, it was found that $\mathrm{KT}$, compared to a rigid tape, offers less stability, but, in comparison with the non-use of stabilizers, KT decreases proprioceptive deficits. According to Murray and Husk ${ }^{19}$, elastic tape can act as a proprioceptive facilitator in the acute phase of the injury.

Studies evaluating the efficacy of KT have somewhat controversial results as to its functionality. A recent study ${ }^{20}$ found that elastic tape did not influence the functional performance of soccer athletes. However, another study ${ }^{13}$ found that $\mathrm{KT}$ reduced the rate of occurrence ankle sprains.

Even with its elastic component, it is possible that $\mathrm{KT}$ restricts joint motion, as observed in the study by Gunay ${ }^{22}$. In such study there was, on average, a 10.7 degree restriction for inversion and eversion, pointing to a significant difference between placebo and KT. Delahunt et al. ${ }^{23}$ showed that the use of elastic tape did not increase the distances in SEBT compared to the control. One of the possibilities for such outcome is that KT action may restrict ankle movements.

One of the causes that can influence the perception of the patient using KT is the psychological factor. A placebo method is defined as "any therapeutic procedure (or therapeutic component) used deliberately to obtain an effect on a patient, symptom, syndrome or disease," but which has no specific activity to treat this condition. A placebo method is based on the psychological expectation that the treatment will improve symptoms ${ }^{14}$. Thus, it should be considered as an additional analysis of the effectiveness of functional elastic tape.

The effects of KT are still being discussed. A recent study ${ }^{12}$ sought to observe the effect of placebo tapes, and the results suggest that the placebo method may influence functional performance. This change in perception with a placebo may be because simply applying the tape, even without tension, led participants to believe that it would allow them to perform better. In Sawkins and Refshauge ${ }^{14}$, participants reported 
that there was an increase in the perception of stability, confidence, and safety with the placebo method in both the unipedal jump test and the modified SEBT. None of the participants reported improvements in any of the functional tests with the control condition.

Possible limitations found in the present study may have influenced the results: the interval for the execution of the two tests was greater than the desired one, and also familiarization with the SEBT in the second test could facilitate its accomplishment. Other factor would be the methodological variation, since the sample size and statistical calculations are different when compared to other studies in the literature.

\section{CONCLUSION}

From the study carried out it can be observed that elastic tape does not provoke positive effects on joint stabilization in athletes with and without chronic instability, taking into account their functionality. It would be of great use that more studies were carried out in order to verify this implement as an ankle stabilizer because the literature is still fairly divergent.

All authors declare no potential conflict of interest related to this article.

AUTHORS' CONTRIBUTIONS: Each author made significant individual contributions to this manuscript. HHS (0000-0001-8541-0866)* and AMP (0000-0001-9781-1413)* were the main contributors in the drafting of the manuscript. HHS (0000-0001-8541-0866)*, LCG (0000-0003-4166-9176)* and GPF $(0000-0002-3221-7680)^{*}$ contributed to the collection of data with the athletes. IP (0000-0002-3109-3866)* conducted the joint tests. HHS (0000-0001-8541-0866) and AMP (0000-0001-9781-1413)* contributed to the intellectual conception of the study and discussed the results and final review of the manuscript. AMP (0000-0001-9781-1413)*, IP (0000-0002-3109-3866)* and RFLC (0000-0002-9913-2163)* reviewed the article for publication. All authors contributed to the intellectual concept of the study. ${ }^{*} \mathrm{ORCID}$ (Open Researcher and Contributor ID).

\section{REFERENCES}

1. Araújo SJC, Simões AR, Cavalcante CLM, Moraes BRM. A aplicabilidade do recurso Kinesio Taping ${ }^{\circledR}$ nas lesões desportivas: Uma Revisão de Liiteratura. Revista Pesquisa em Fisioterapia. 2014;4(3):189-96.

2. Briem K, Eythörsdöttir H, Magnúsdóttir RG, Pálmarsson R, RúnarsdötttirT, Sveinsson T. Effects of kinesio tape compared with nonelastic sports tape and the untaped ankle during a sudden inversion perturbation in male athletes. J Orthop Sports Phys Ther. 2011;41(5):328-35.

3. Zavarise SF, Martelli A. Mecanismos Neurofisiológicos da Bandagem Funcional no Estímulo Somatosensorial. Rev Saúde e Des Humano. 2014;2(2):39-49.

4. Tremblay F, Karam S. Kinesio-Taping Application and Corticospinal Excitability at the Ankle Joint. J Athl Train. 2015;50(8):840-6.

5. Pacheco AM, Vaz M, Pacheco I. Avaliação do tempo de resposta eletromiográfica em atletas de voleibol e não atletas que sofreram entorse de tornozelo. Rev Bras Med Esporte. 2005;11(6):325-30.

6. Peres MM, Cecchini L, Pacheco I, Pacheco AM. Efeitos do treinamento proprioceptivo na estabilidade do tornozelo em atletas de voleibol. Rev Bras Med Esporte. 2014;20(2):146-50.

7. Bicci S, Karatas N, Baltaci G. Effect of athletic taping and kinesiotaping on measurements of functional performance in basketball players with chronic inversion ankle sprains. Int J Sports Phys Ther. 2012;7(2):154-66.

8. Brum GR, Miotto M, Tadiello GS, Schmitt VM, De Marchi T, Bonetti LV. A utilização da bandagem na estabilidade do tornozelo em atletas de basquetebol. ConScientiae Saúde. 2012;11(3):491-7.

9. Williams S, Whatman C, Hume PA, Sheerin K. Kinesio Taping in Treatment and Prevention of Sports Injuries. A Meta-Analysis of the Evidence for its Effectiveness. Sports Med. 2012;42(2):153-64.

10. Souza RF. O que é um estudo clínico randomizado? Revista da Faculdade de Medicina de Ribeirão Preto e do Hospital das Clínicas de FMRP. 2009;42(1):3-8.

11. Kuni B, Mussler J, Kalkum E, Schmitt H, Wolf S. Effect of kinesiotaping, non-elastic taping and bracing on segmental foot kinematics during drop landing in healthy subjects and subjects with chronic ankle instability. Physiotherapy. 2016;102(3):287-93.

12. Cheung RT, Yau QK, Wong K, Lau P, So A, Chan N, et al. Kinesiology tape does not promote vertical jumping performance: A deceptive crossover trial. Man Ther. 2016;21:89-93.
13. Dizon JM, Reyes JJ. A systematic review on the effectiveness of external ankle supports in the prevention of inversion ankle sprains among elite and recreational players. J Sci Med Sport. 2010;13(3):309-17.

14. Sawkins K, Refshauge K, Kilbreath S, Raymond J. The placebo effect of ankle taping in ankle instability. Med Sci Sports Exerc. 2007;39(5):781-7.

15. Nunes GS, de Noronha M, Cunha HS, Ruschel C, Borges NG Jr. Effect of kinesio taping on jumping and balance in athletes: a crossover randomized controlled trial. J Strength Cond Res. 2013;27(11):3183-9.

16. Halseth T, McChesney JW, Debeliso M, Vaughn R, Lien J. The effects of kinesio ${ }^{\mathrm{TM}}$ taping on proprioception at the ankle. J Sports Sci Med. 2004;3(1):1-7.

17. Hettle D, Linton D, Baker JS, Donoghue O. The Effect of Kinesiotaping on Functional Performance in Chronic Ankle Instability - Preliminary Study. Clin Res Foot Ankle. 2013;1:105-10.

18. Kwiatkowska ZJ, Rajkowska-Labon E, Skrobot W, Bakula S, Szamotulska J. Application of Kinesio Taping ${ }^{\odot}$ for Treatment of Sports Injuries. Med Sport Press. 2007;13(1):130-4.

19. Murray HM, Husk LJ. The effects of kinesio taping ${ }^{\text {TM }}$ on proprioception in the ankle and in the knee. Orthop Sports Phys Ther. 2001;31(1):A-37.

20. Prianti BM, Prianti TSM, Mendes IS, Júnior, ARP, Lima MO, Pupio FL. Efeito da bandagem funcional de tornozelo no equilíbrio e na atividade mioelétrica durante o chute futebolístico. XXIV Congresso Brasileiro de Engenharia Biomédica - CBEB 2014.

21. Mickel TJ, Bottoni CR, Tsuji G, Chang K, Baum L, Tokushige KA. Prophylactic bracing versus taping for the prevention of ankle sprains in high school athletes: a prospective, randomized trial. J Foot Ankle Surg. 2006;45(6):360-5.

22. Günay S, Karaduman A, Oztürk BB. Effects of Aircast brace and elastic bandag e on physical performance of athletes after ankle injuries. Acta Orthop Traumatol Turc. 2014;48(1):10-6.

23. Delahunt E, McGrath A, Doran N, Coughlan GF. Effect of taping on actual and perceived dynamic postural stability in persons with chronic ankle instability. Arch Phys Med Rehabil. 2010;91(9):1383-9.

24. Shapiro AK. Factor contributing to the placebo effect. Their implications for psychotherapy. Am J Psychother.1964;SUPPL 1:73-88 